\title{
SKETCH-UP
}

\section{A changeable day in the life of Venus}

Nat. Geosci. https://doi.org/10.1038/s41561-018-0157-x (2018)

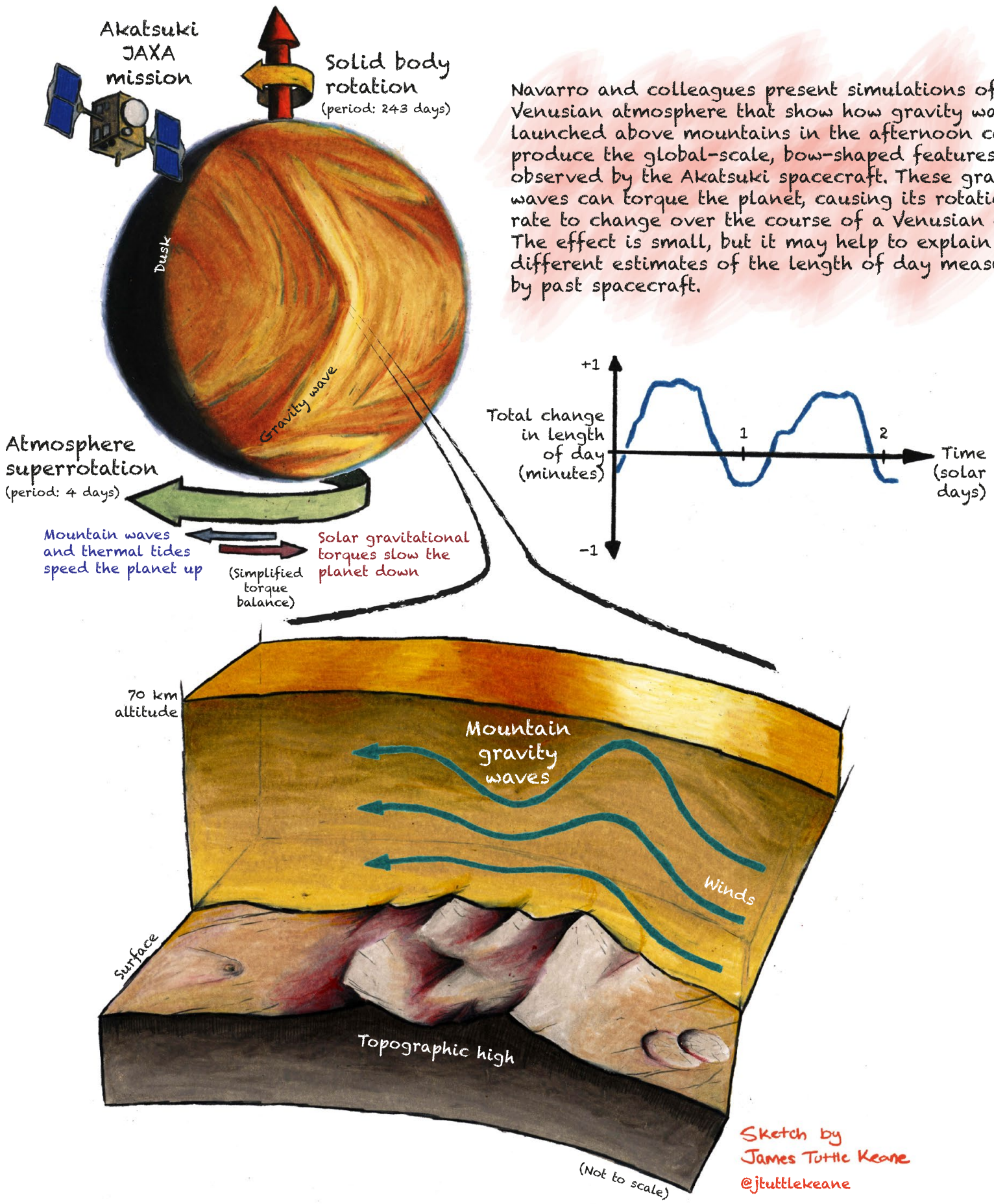

Published online: 18 June 2018

https://doi.org/10.1038/s41561-018-0179-4 